\title{
Effect of Nutrient Management Modules on Growth, Yield Attributes and Yield of Wheat
}

\author{
Dinesh Kumar ${ }^{1 *}$, Ved Prakash, Prashant Singh², Sanjay Kumar², \\ Ajit Kumar ${ }^{2}$ and Chandan Kumar ${ }^{1}$ \\ ${ }^{1}$ Department of Soil Science and Agriculture Chemistry, Narendra Deva University of \\ Agriculture and Technology, Narendra Nagar, Faizabad, U.P., India \\ ${ }^{2}$ Department of Agronomy, Narendra Deva University of Agriculture and Technology, \\ Narendra Nagar, Faizabad, U.P., India \\ *Corresponding author
}

\begin{tabular}{|c|c|}
\hline & A B S T R A C T \\
\hline & The field experiment was conducted to study the effect of nutrient management modules \\
\hline $\begin{array}{l}\text { Ke y w o r d s } \\
\text { Growth, yield, } \\
\text { wheat, FYM and } \\
\text { vermicompost. }\end{array}$ & 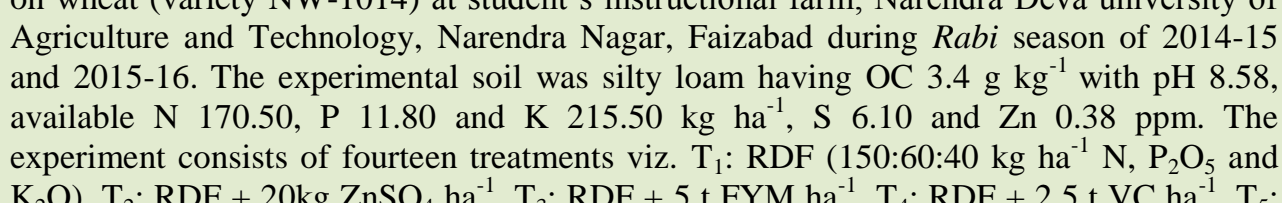 \\
\hline Article Info & $\mathrm{RDF}+5 \mathrm{t} \mathrm{FYM}+20 \mathrm{~kg} \mathrm{ZnSO}_{4} \mathrm{ha}^{-1}, \mathrm{~T}_{6}: \mathrm{RDF}+2.5 \mathrm{t} \mathrm{VC}+20 \mathrm{~kg} \mathrm{ZnSO}_{4} \mathrm{ha}^{-1}, \mathrm{~T}_{7}: 75 \%$ \\
\hline $\begin{array}{l}\text { Accepted: } \\
\text { 04 October } 2017 \\
\text { Available Online: } \\
10 \text { December } 2017\end{array}$ & $\begin{array}{l}\mathrm{RDF}, \mathrm{T}_{8}: 75 \% \mathrm{RDF}+20 \mathrm{~kg} \mathrm{ZnSO}_{4} \mathrm{ha}^{-1}, \mathrm{~T}_{9}: 75 \% \mathrm{RDF}+10 \mathrm{t} \mathrm{FYM} \mathrm{ha}{ }^{-1}, \mathrm{~T}_{10}: 75 \% \mathrm{RDF}+ \\
5 \mathrm{t} \mathrm{VC} \mathrm{ha}{ }^{-1}, \mathrm{~T}_{11}: 75 \% \mathrm{RDF}+10 \mathrm{t} \mathrm{FYM}+20 \mathrm{~kg} \mathrm{ZnSO} \mathrm{ha}^{-1}, \mathrm{~T}_{12}: 75 \% \mathrm{RDF}+5 \mathrm{t} \mathrm{VC}+20 \\
\mathrm{~kg} \mathrm{ZnSO}_{4} \mathrm{ha}^{-1}, \mathrm{~T}_{13}: 125 \% \mathrm{RDF}, \mathrm{T}_{14}: 125 \% \mathrm{RDF}+20 \mathrm{~kg} \mathrm{ZnSO}_{4} \mathrm{ha}^{-1} \text {. The results revealed } \\
\text { that the application of } 100 \% \text { recommended dose of fertilizer }(\mathrm{RDF})+\text { vermicompost @ } 2.5 \\
\mathrm{t} \mathrm{ha}^{-1}+\mathrm{ZnSO}_{4} @ 20 \mathrm{~kg} \mathrm{ha}^{-1} \text { as well as } 100 \% \mathrm{RDF}+\mathrm{FYM} @ 2.5 \mathrm{t} \mathrm{ha}^{-1}+\mathrm{ZnSO}_{4} @ 20 \mathrm{~kg} \\
\mathrm{ha}^{-1} \text { recorded higher yield attributes and yield than rest of the treatments. }\end{array}$ \\
\hline
\end{tabular}

\section{Introduction}

Wheat (Triticum aestivum L.) is one of the most important cereal crops of the world. Among the world's most important food grains, it ranks next to rice. It is eaten in various forms by more than one billion in the world. Wheat straw is a good source of feed for a large population of the cattle in our country. It ranks second in the world among the cereals both in respect of acreage (231.0 $\mathrm{m}$ ha) and production (727.87 metric t.) (Ministry of Agri. GOI 2015-16). India is the second largest producer of wheat in the world.
It is a pre-dominant winter season crop of north western plain zones and during 201516, production in India was 95.85 million tons from an area of 30.47 million hectares with productivity of 2.99 tones $\mathrm{ha}^{-1}$ (Economic survey, GOI, 2015-16).

UP ranks first in respect of crop coverage area (9.64 million hectares) and production (30.00 million tons) but average productivity is low (3.11 $\mathrm{t} \mathrm{ha}^{-1}$ ) (FAO, STATE -2014-15). The most significant results are obtained, when we 
use organic manures in the combination of inorganic fertilizers (Patra et al., 1999). Nitrogen is major structural nutrient of the cell along with $\mathrm{P}$ and $\mathrm{K}$. It helps in building up vegetative growth of plants. The deficiency of nitrogen badly affects the crop growth and causes shrivelling of grain and poor crop yield. Phosphorus is also important major plant nutrient for better crop production. It is necessary for photosyntehsis. Potassium is the third major plant nutrient and plays very important role in photosynthesis and translocation of nutrients from leaves to the seed. Organic manures with the combination of chemical fertilizers, increases growth, grain and straw yield of wheat crop. Zinc is involved in protein and carbohydrate metabolism through several enzyme systems. Zinc increases the grain and straw yield of wheat with increasing levels of zinc application.

\section{Materials and Methods}

Field experiments were conducted during the rabi season 2014-15 and 2015-16 at students instructional farm, Narendra Deva university of Agriculture \& Technology Narendra Nagar Faizabad. The experimental soil was silty loam having organic carbon $3.40 \mathrm{~g} \mathrm{~kg}^{-1}$ with $\mathrm{pH} 8.58$, available $\mathrm{N} 170.50, \mathrm{P} 11.80$ and $\mathrm{K}$ $215.50 \mathrm{~kg} \mathrm{ha}^{-1}$, S 6.1 and $\mathrm{Zn} 0.38 \mathrm{ppm}$.

The experiment was laid out in randomized block design with three replications. Vermicompost and FYM were applied 15 days before sowing as per treatment. Wheat cultivar NW-1014 was sown in rows $20 \mathrm{~cm}$ apart on $26^{\text {th }}$ November in 2014 and $17^{\text {th }}$ November in 2015 and harvested on $14^{\text {th }}$ April 2015 and 29 ${ }^{\text {th }}$ April in 2016, respectively. Half of nitrogen and full dose of phosphorus and potash were applied at the time of sowing as per treatment combination. The remaining nitrogen as per treatment was top dressed after first irrigation. N, P, K and
Zn were applied through urea, DAP, muriate of potash and zinc sulphate, respectively. The crop received four uniform irrigations (at crown root initiation, tillering, flowering and milking stages). The yield parameters and yields were recorded and analyzed as per Gomez and Gomez (1984). The treatment comparisons were made using t-test at $5 \%$ level of significance.

\section{Results and Discussion}

\section{Effect on growth, yield attributes and yield}

Two years (2014-15 and 2015-16) pooled data (Table 1) revealed that the maximum plant height $(97.45 \mathrm{~cm})$ recorded with the treatment $\mathrm{T}_{6}(100 \% \mathrm{RDF}+2.5 \mathrm{t} \mathrm{VC}+20 \mathrm{~kg}$ $\mathrm{ZnSO}_{4} \mathrm{ha}^{-1}$ ) was statistically at par with $\mathrm{T}_{4}, \mathrm{~T}_{5}$, $\mathrm{T}_{11}$ and $\mathrm{T}_{12}$ and significantly superior over rest of the treatments. Higher plant height in $\mathrm{T}_{4}, \mathrm{~T}_{5}, \mathrm{~T}_{6}, \mathrm{~T}_{11}$ and $\mathrm{T}_{12}$ might be due to higher nitrogen content applied through inorganic and organic sources. Similar kind of result has been reported by Roberts et al., (2007).

The data with respect to effective shoots $\mathrm{m}^{-2}$ as influenced by various treatments have been presented in Table 1. It clearly indicates that the maximum effective shoots (423.05) recorded with $\mathrm{T}_{6}(100 \% \mathrm{RDF}+2.5 \mathrm{t} \mathrm{VC}+20$ $\mathrm{kg} \mathrm{ZnSO}_{4} \mathrm{ha}^{-1}$ ) was statistically at par with $\mathrm{T}_{4}, \mathrm{~T}_{5}, \mathrm{~T}_{11}$ and $\mathrm{T}_{12}$ and significantly superior over rest of the treatments.

The data with respect to no. of grains spike ${ }^{-1}$ as influenced by various treatments have been presented in Table 1. It clearly indicates that the maximum no. of grains (52.67) recorded with $\mathrm{T}_{6}\left(100 \% \mathrm{RDF}+2.5 \mathrm{t} \mathrm{VC}+20 \mathrm{~kg} \mathrm{ZnSO}_{4}\right.$ $\mathrm{ha}^{-1}$ ) was statistically at par with $\mathrm{T}_{4}, \mathrm{~T}_{5}, \mathrm{~T}_{11}$ and $T_{12}$ and significantly superior over rest of the treatments. Number of grains spike ${ }^{-1}$ also increased significantly by integrating FYM and vermicompost or supplementary nutrients like, zinc with NPK. Maximum values of 
yield contributing characters were recorded under combined application of $100 \%$ $\mathrm{RDF}+2.5 \mathrm{t} \mathrm{VC}+20 \mathrm{~kg} \mathrm{ZnSO}_{4} \mathrm{ha}^{-1}$, indicating the supplementing the inorganic fertilizers with FYM and vermicompost improved the general soil environment, which help to improve the wheat growth and yield contributing characters. Similar findings were also reported by Nehra et al., (2001) and Chandel et al., (2014).

Table.1 Effect of nutrient management modules on growth, yield attributes and yield of wheat (pooled of two years)

\begin{tabular}{|c|c|c|c|c|c|c|}
\hline \multirow{2}{*}{ Treatments } & \multirow{2}{*}{$\begin{array}{l}\text { Plant } \\
\text { height } \\
\text { (cm) }\end{array}$} & \multirow{2}{*}{$\begin{array}{l}\text { Effective } \\
\text { shoot } \mathbf{m}^{-2}\end{array}$} & \multirow{2}{*}{$\begin{array}{l}\text { No. of } \\
\text { grains } \\
\text { spike }^{-1}\end{array}$} & \multirow{2}{*}{$\begin{array}{c}\text { Test } \\
\text { weight }(\mathrm{g})\end{array}$} & \multicolumn{2}{|c|}{ Yield $\left(q\right.$ ha $\left.^{-1}\right)$} \\
\hline & & & & & Grain & Straw \\
\hline $\mathrm{T}_{1}$ & 82.94 & 360.05 & 41.93 & 38.65 & 41.78 & 62.67 \\
\hline$T_{2}$ & 87.65 & 380.50 & 44.62 & 39.37 & 42.73 & 66.23 \\
\hline$T_{3}$ & 89.54 & 388.69 & 46.30 & 39.66 & 45.10 & 67.17 \\
\hline $\mathrm{T}_{4}$ & 90.95 & 394.82 & 48.64 & 39.90 & 45.81 & 68.21 \\
\hline $\mathrm{T}_{5}$ & 96.13 & 417.33 & 51.33 & 40.82 & 48.05 & 69.28 \\
\hline $\mathrm{T}_{6}$ & 97.45 & 423.05 & 52.67 & 41.99 & 50.80 & 71.07 \\
\hline $\mathrm{T}_{7}$ & 79.66 & 345.83 & 39.63 & 37.74 & 35.61 & 56.97 \\
\hline $\mathrm{T}_{8}$ & 81.19 & 352.44 & 39.78 & 38.33 & 36.22 & 57.96 \\
\hline $\mathrm{T}_{9}$ & 82.27 & 357.15 & 40.92 & 38.49 & 36.92 & 59.26 \\
\hline $\mathrm{T}_{10}$ & 84.82 & 368.23 & 43.28 & 39.30 & 42.35 & 64.09 \\
\hline $\mathrm{T}_{11}$ & 92.36 & 400.96 & 49.98 & 40.08 & 46.53 & 67.31 \\
\hline $\mathrm{T}_{12}$ & 93.31 & 405.05 & 50.66 & 40.57 & 47.95 & 68.24 \\
\hline $\mathrm{T}_{13}$ & 83.88 & 364.14 & 42.75 & 39.14 & 42.06 & 63.67 \\
\hline$T_{14}$ & 88.12 & 382.55 & 45.29 & 39.56 & 44.39 & 66.59 \\
\hline SEm \pm & 2.71 & 11.78 & 1.42 & 1.23 & 1.34 & 1.89 \\
\hline C.D. at 5\% & 7.70 & 33.44 & 4.03 & NS & 3.79 & 5.35 \\
\hline
\end{tabular}

$\mathrm{T}_{1}: \operatorname{RDF}\left(150: 60: 40 \mathrm{~kg} \mathrm{ha}^{-1} \mathrm{NPK}\right), \mathrm{T}_{2}: \mathrm{RDF}+20 \mathrm{~kg} \mathrm{ZnSO}_{4} \mathrm{ha}^{-1}, \mathrm{~T}_{3}: \mathrm{RDF}+5 \mathrm{t} \mathrm{FYM} \mathrm{ha}^{-1}, \mathrm{~T}_{4}: \mathrm{RDF}+2.5 \mathrm{t} \mathrm{VC} \mathrm{ha}^{-1}$, $\mathrm{T}_{5}: \mathrm{RDF}+5 \mathrm{t} \mathrm{FYM}+20 \mathrm{~kg} \mathrm{ZnSO}_{4} \mathrm{ha}^{-1}, \mathrm{~T}_{6}: \mathrm{RDF}+2.5 \mathrm{t} \mathrm{VC}+20 \mathrm{~kg} \mathrm{ZnSO}_{4} \mathrm{ha}^{-1}, \mathrm{~T}_{7}: 75 \% \mathrm{RDF}\left(112.50: 50: 45 \mathrm{~kg} \mathrm{ha}^{-}\right.$ $\left.{ }^{1}\right), \mathrm{T}_{8}: 75 \% \mathrm{RDF}+20 \mathrm{~kg} \mathrm{ZnSO}_{4} \mathrm{ha}^{-1}, \mathrm{~T}_{9}: 75 \% \mathrm{RDF}+10 \mathrm{t} \mathrm{FYM} \mathrm{ha}^{-1}, \mathrm{~T}_{10}: 75 \% \mathrm{RDF}+5 \mathrm{t} \mathrm{VC} \mathrm{ha}^{-1}, \mathrm{~T}_{11}: 75 \% \mathrm{RDF}$ $+10 \mathrm{t} \mathrm{FYM} \mathrm{+} 20 \mathrm{~kg} \mathrm{ZnSO}_{4} \mathrm{ha}^{-1}, \mathrm{~T}_{12}: 75 \% \mathrm{RDF}+5 \mathrm{t} \mathrm{VC}+20 \mathrm{~kg} \mathrm{ZnSO}_{4} \mathrm{ha}^{-1}, \mathrm{~T}_{13}: 125 \% \mathrm{RDF}(187.50: 75: 50 \mathrm{~kg} \mathrm{ha}$ $\left.{ }^{1}\right), \mathrm{T}_{14}: 125 \% \mathrm{RDF}+20 \mathrm{~kg} \mathrm{ZnSO}_{4} \mathrm{ha}^{-1}$,

The data with respect to test weight as influenced by various treatments have been presented in Table 1. It clearly indicates the non-significant differences on test weight that the maximum test weight (41.99 g) recorded with $\mathrm{T}_{6}(100 \% \mathrm{RDF}+2.5 \mathrm{t} \mathrm{VC}+20 \mathrm{~kg} \mathrm{ZnSO}$ $\mathrm{ha}^{-1}$ ) was significantly superior over rest of the treatments. Test weight and no. of grain spike $^{-1}$ also increased significantly by integrating FYM and vermicompost or supplementary nutrients like, zinc with NPK. However, maximum values of yield contributing characters were recorded under combined application of $100 \% \mathrm{RDF}+2.5 \mathrm{t}$ $\mathrm{VC}+20 \mathrm{~kg} \mathrm{ZnSO}_{4} \mathrm{ha}^{-1}$, indicating that supplementing the inorganic fertilizers with FYM and vermicompost improved the general soil environment, which helped to improve the wheat growth and yield contributing characters.

The grain and straw yield were significantly influenced by different nutrient management modules. Treatment $\mathrm{T}_{6}(100 \% \mathrm{RDF}+2.5 \mathrm{t} \mathrm{VC}$ + $20 \mathrm{~kg} \mathrm{ZnSO}_{4} \mathrm{ha}^{-1}$ ) recorded highest grain and straw yield (50.81 and $71.07 \mathrm{q} \mathrm{ha}^{-1}$, 
respectively) which were statistically at par with $\mathrm{T}_{5}(100 \% \mathrm{RDF}+5 \mathrm{t} \mathrm{FYM}+20 \mathrm{~kg}$ $\left.\mathrm{ZnSO}_{4} \mathrm{ha}^{-1}\right), \mathrm{T}_{11}(75 \% \mathrm{RDF}+10 \mathrm{t} \mathrm{FYM} \mathrm{+} 20$ $\left.\mathrm{kg} \mathrm{ZnSO}_{4} \mathrm{ha}^{-1}\right)$ and $\mathrm{T}_{12}(75 \% \mathrm{RDF}+5 \mathrm{t}$ $\mathrm{VC}+20 \mathrm{~kg} \quad \mathrm{ZnSO}_{4} \quad \mathrm{ha}^{-1}$ ) and significantly superior over rest of the treatments. $\mathrm{T}_{7}(75 \%$ RDF) was recorded lowest grain and straw yield (35.61 and $56.97 \mathrm{q} \mathrm{ha}^{-1}$, respectively). Higher grain and straw yield in treatments $\mathrm{T}_{6}$, $\mathrm{T}_{5}, \mathrm{~T}_{12}$ and $\mathrm{T}_{11}$ is might be due to the combined effect of availability of various nutrients to the plant at proper growth stages through the various means i.e. chemical (macro and micro nutrients) and organic sources (FYM and vermicompost). Treatment $\mathrm{T}_{6}$ showed highest yield which might be due to the balanced use of essential macro and micro nutrients through inorganic and organic sources. Patil and Bhilare (2000), Davari et al., (2012) and Kausik and Ray (2008) reported similar results in conformity with the results of present study.

On the basis of results summarized above, it may be calculated that the treatment module of $\mathrm{T}_{6}-100 \% \mathrm{RDF}+2.5 \mathrm{t} \mathrm{VC}+20 \mathrm{~kg} \mathrm{ZnSO}_{4}$ $\mathrm{ha}^{-1}$ resulted highest growth, yield attributes and yield of wheat.

\section{References}

Chandel, B. S., Singh, H. and Singh, B. (2014). Direct and residual effect of nutrient management in wheat-maize cropping sequence. J. Indian Society Soil Science, 61(2):126-130.
Davari, M.R.; Sharma, S.N. and Rirzakhani, M. (2012). The effect of combinations of organic materials and bio-fertilizers on productivity, grain quality, nutrient uptake and economics in organic farming of wheat. J. Organic Sys, 7 (2): 26-35.

Gomez, K. A. and Gomez, A. A. (1984). Statistical Procedure for Agricultural Research. IS'Edn, John Wiley and Sons pub., New York, pp. 28-91.

Kausik Nag; and Ray, A.K.S. (2008). Response of late sown wheat (Triticum aestivum) to integrated nutrient management. Environment and Ecology, 26 (1): 8-10.

Nehra, A.S.; Hooda, I.S. and Singh, K.P. (2001). Effect of integrated nutrient management on growth and yield of wheat (Triticum aestivum). Indian J. of Agron. 46 (1):112-117.

Patil, V.S. and Bhilare, R.L. (2000). Effect of vermicompost prepared from different organic sources on growth and yield of wheat. J. Maharashtra Agri. Univ. 25 (3): 305-306.

Patra, A.; Panda, D.; Patra, B.C. and Karnatar, A.J. (1999). Effect of FYM, Zinc and NPK fertilizers on yield component and yield of wheat after winter rice in West Bengal. Journal of Interacademicia, 16.

Roberts, P.; Jones, G. and D.L. (2007). Yield response of wheat (Triticum aestivum) to vermicompost application. Compost Science and utilization, 15(1): 6-15.

\section{How to cite this article:}

Dinesh Kumar, Ved Prakash, Prashant Singh, Sanjay Kumar, Ajit Kumar and Chandan Kumar. 2017. Effect of Nutrient Management Modules on Growth, Yield Attributes and Yield of Wheat. Int.J.Curr.Microbiol.App.Sci. 6(12): 366-369. doi: https://doi.org/10.20546/ijcmas.2017.612.044 